\title{
İşe Angaje Olma ve İş Tatmini Arasındaki İlişki: Hekim Ve Hemşireler Üzerine Nicel Bir Araştırma
}

\author{
Elif Türkan ARSLAN* Hüseyin DEMIR**
}

\begin{abstract}
$\ddot{O} Z$
$B u$ çalışmanın temel amacı, hekim ve hemşirelerin işe angaje olma ve iş tatmin düzeylerini belirlemek ve işe angaje olma ve iş tatmini arasındaki ilişkiyi araştırmaktır. Çalışma bu temel amaç dişında ayrıca demografik değişkenler ile işe angaje olma ve iş tatmini arasındaki ilişkiyi tespit etmeyi amaçlamaktadır. Alan araştırmasında anket yöntemi benimsenmiştir. Yüz yüze anket yöntemi kullanılarak 44 hemşire ve 16 hekime ulaşılmıştır. Elde edilen veriler SPSS 20.0 programı kullanılarak yüzde (\%), frekans $(f)$, aritmetik ortalama, Kruskal Wallis H, Mann Whitney U ve Spearman's rho korelasyon analizleri ile incelenmiştir. Analizler neticesinde hekim ve hemşirelerin işe angaje olma ve iş tatmin düzeylerinin yüksek; işe angaje olma ve iş tatmin düzeyi arasında istatistiksel olarak pozitif yönlü anlamlı bir ilişki olduğu saptanmıştır. Işse angaje düzeyinin cinsiyete göre, iş tatmin düzeyinin ise diğer değişkenlerin tamamına göre farklılık gösterdiği saptanmıştır. Hekim ve hemşirelerin işe angaje olma ve iş tatmin düzeyleri genel olarak yüksektir. Ancak hemşirelerin hekimlere nazaran iş tatmin düzeylerinin daha düşük olduğu anlaşılmıștır. Hemșirelerin iş tatmin düzeylerinin çeşitli motive edici faktörlerin kullanılması ile arttırlmasının klinik hizmetlerde kalitenin arttırlmasında oldukça gerekli ve önemli olduğu düşünülmektedir.
\end{abstract}

Anahtar kelimeler: İşe angaje olma, iş tatmini, săglık hizmetleri, hekim, hemşire

JEL Sinıflandırması: M1, M120, I1

The Relationship Between Job Satisfaction and Work Engagement: A Quantitative Research on Nurses and Physician

\begin{abstract}
This study aims to determine work engagement and job satisfaction level of physicians and nurses, and examine whether there is a correlation between the two variables. Also, it aims to determine whether work engagement and job satisfaction levels differ by demographic variables. Questionnare method was utilized in the study. Questionnare consists of two scale which are "Work Engagement" and "Minnesota Job Satisfaction". It was reached 44 nurses and 16 physicians by using face to face questionnare method. Data were examined through SPSS 20.0 program by using percent (\%), frequency (f), arithmetic average, Kruskal Wallis H, Mann Whitney $U$ tests and Spearman's rho correlation analyze. The result of the analyzes, it is revaled that work engagement and job satisfaction level of physician and nurses are high; there is a significant relationship pozitive-way between work engagement and job satisfaction. Work engagement differs bysex, also, job satisfaction level differs by all of other demographic variables. Work engagement and job satisfaction levels of physician and nurses are in generally high. But, it is understood that nurses have low job satisfaction level contrary to physician. It is believed that the using of factors which increase motivationof nurses are essential and important for increasing quality of clinical services.
\end{abstract}

Key Words: Work engagement, job satisfaction, health care, physician, nurse

JEL Classification: M1, M120, I1

* Yrd. Doç. Dr. İzmir Kâtip Çelebi Üniversitesi, İktisadi ve İdari Bilimler Fakültesi, Sağlık Yönetimi Bölümü, elifturkanarslan@gmail.com

** Arş. Gör. Hacettepe Üniversitesi, İktisadi ve İdari Bilimler Fakültesi, Sağlık Yönetimi Bölümü, huseyin.demir1992@outlook.com 


\section{GíRIŞ̧}

Dünya Sağl1k Örgütü sağl1k profesyonellerini sağl1k sisteminin temel yap1 taşlarından biri olarak belirtmektedir.Sağlık çalışanlarının insanlara kendilerine doğuştan bir hak olan yaşama hakkının bir şartı niteliğinde olan sağlık hizmetini sunma hususunda istekli olmaları ve yaptıkları işten tatmin düzeylerinin yüksek olması gerekmektedir. Sağlik hizmetlerinde ihmal, dikkatsizlik, kusur vb. durumlar hastalarda geçici ve kalıcı hasarlara yol açabilmektedir. Tıbbi hataların önlenmesi, klinik hizmetlerde kalite ve verimliliğin sağlanması, hasta memnuniyetinin artması ve insanların sağlı statüsünün iyileştirilmesi için sağlık çalışanlarının ve özellikle de hasta ile en fazla etkileşim içerisinde bulunan hekim ve hemşirelerin işe angaje olma ve iş tatmin düzeylerinin yüksek olması gerekmektedir. Sağlık hizmetinin bir ekip hizmeti niteliğinde olması hizmetin her bir biriminin güçlü olması esasına dayanmaktadır. Sağlı hizmetinin her sürecinde sorumlu olan sağlık çalışanlarının işlerine gönülden bağlı olmaları ve tatmin düzeylerinin yüksek olması son derece gereklidir. Poliklinik, klinik, laboratuvar, ameliyathane, yoğun bakım vb. hastanenin tüm birimlerinde görevli sağlık çalışanlarının söz konusu özellikleri taşıması gerekmektedir. Çünkü, hastane içerisinde belirtilen bu birimler arasındaki ilişki müşteri-tedarikçi ilişkisine benzemektedir. Bir birimin iyi veya kötü performans göstermesi diğer birimlerin performansını oldukça etkilemektedir.

Bu kapsamda planlanan çalışmanın amacı, hekim ve hemşirelerin işe angaje olma ve iş tatmin düzeylerinin belirlenmesi ve diğer yandan işe angaje olma ile iş tatmini düzeyi arasındaki ilişkinin araştırılmasıdır. Çalışma bu temel amaç dışında ayrıca çeşitli demografik değişkenler ile işe angaje olma ve iş tatmini arasındaki ilişkiyi tespit etmeyi de amaçlamaktadır.

\section{I.İŞE ANGAJE OLMA}

Örgüt içerisinde çalışanların kendilerini tükenmiş olarak hissetmesi sosyal bir sorundur, iş çevresiyle ilgilidir ve örgüte ilişkin olumsuz bir durumdur (Schaufeli, 2015: 448). Tükenmişlik olarak ifade edilen kavram, örgütsel performansta kritik öneme sahiptir (Mosadeghrad ve Ferdosi, 2013: 121). Duygusal tükenme, duyarsızlaşma ve kişisel başarı olmak üzere üç temel boyuttan oluşan tükenmişlik, örgütlerin sürdürülebilir bir iş anlayışı geliştirmelerinde büyük bir engel oluşturmakta ve kronik hale geldiğinde üstesinden gelinemeyecek bir noktaya varmaktadır (Maslach ve Leiter, 2008: 498). Tükenmişliğin tersine çevrilmesi olarak tanımlanan işe angaje olma ise, yönetim literatüründe son zamanlarda üzerinde daha fazla durulmaya başlanan çalışma alanlarından biri olarak öne çıkmıştır (Ravikumar, 2013: 177). Üzerinde uzlaşılmış kesin bir tanımı olmayan bu kavramı Markos ve Sridevi (2010: 90), çalışanın örgütün hedeflerini başarma noktasındaki istekliliği, sürdürülebilir bir iş yükü ile büyük bir çaba içerisinde olma olarak ifade etmektedir. Robinson ve diğerleri (2004: 15)'ne göre bu kavram, çalışanın örgüte ve örgütün değerlerine karşı tutumlarıdır. İşe angaje olma kavramı, farklı çalışmalarda farklı şekillerde adlandırılmaktadır. Bu çalışmalardan bazıları; "işe cezbolma" (Özer ve diğerleri, 2015), "işle 
bütünleşme" (Ardıç ve Polatç1, 2009), "işe angaje olma" (Güneşer, 2007; Markos ve Sridevi, 2010), "işe gönülden adanma" (Bal, 2009), "işe tutulma" (Robbins ve Judge, 2012), "işe kapılma" (Öner, 2008) vb. şekildedir. Bu çalışmada ise söz konusu kavramın işe angaje olma şeklinde kullanılması uygun görülmüştür.

İşe angaje olma, bir çalışanın işine bağl1lığı, işini yaparken duyduğu memnuniyet ve coşku olarak ifade edilmektedir. Literatürde henüz gelişme aşamasında olan işe angaje olma kavramı, çalışanların yaptığı işe tutkuyla bağgl olması ve bulundukları örgüte karşı duyduğu derin bir bağ olarak yorumlanmaktadır (Özer ve diğerleri, 2015: 262). İşine angaje olan kişiler işiyle bir bütün olmuş, örgüt için üretken ve verimli kişilerdir. İşine angaje olamayanlar ise işten kopmuş, verimli olmayan kişilerdir; kendilerine sunulan zamanı, enerji ve dikkatlerini yoğunlaştırıp kullanamayan veya gereksiz işlerde kullanan kişilerdir (Ardıç ve Polatçı, 2009: 88).

İşe angaje olma, daha önce belirtildiği gibi tükenmişliğin karşıtı olarak ifade edilmektedir. Tükenmişlikten muzdarip olmuş çalışanların aksine işe angaje olan çalışanlar kendi çalı̧̧ma akiviteleriyle etkili bağlantılar içerisindedir ve iş ortamında daha enerjik olurlar. İşe angaje çalışanlar, kendilerini işin gereklerini yerine getirebilecek bireyler olarak görürler (Schaufeli, 2015: 448). İşe angaje olma, enerjik olma, örgüt işlerine katılım ve verimliliği esas almaktadır. Angaje olma, zihnin belli bir olguyla ilgili pozitif olma durumudur. Kişinin bilişsel olarak kendini işiyle bir bütün olarak değerlendiren, çalışma arkadaşlarıyla samimi ilişkiler geliştirmeyi amaçlayan, örgüt faaliyetleri ile paralellik gösteren çalışanların geliştirmiş olduğu tutumlardır (Maslach ve Leiter, 2008: 499). İşe adanan kişiler, enerjiktir ve etkili iletişim kurarlar. İnsanları iyimser bakış açısıyla yönlendirebilen kişiler olarak öne çıkarlar (Schaufeli, 2015: 449).

Enerjik olma ve angaje olma, literatürde tükenmişlik ve sinizmin direkt karşıtları olarak ifade edilmektedir (Ardıç ve Polatçı, 2009: 89). İşe angaje olma, kişinin yüksek enerji seviyesine sahip olması ve işine olan bağlılığını ifade etmede kullanılmaktadır. İşe angaje olan kişiler yaptıkları işleri anlamlı ve amaç dolu, ilham verici ve önemli görürler. Yaptıkları işi coşkuyla yerine getirir ve işlerinden dolayı gurur duyarlar.

Çalışanlar yaptıkları işin anlamlı ve değerli olduğuna inandıklarında işe daha fazla angaje olma eğilimi gösterirler. Bu konuda yöneticilerin görevi, çalışanları güçlendirme, takım çalışması ve işbirliğini teşvik etme, çalışanların kişisel gelişimlerine olanak sağlama, çalışanlara destek sağlama gibi fonksiyonları yerine getirmektir. Bir işi yapan çalışanların işe tutkunluk düzeyi, örgütün hedeflerinin gerçekleştirilmesinde önemli rol oynamaktadır. İşe tutkunluk düzeyi yüksek çalı̧̧anlar örgüt için önemlidir. Çünkü üretim artışı sağlanmakta, daha az hata yapılmakta, daha fazla müşteri memnuniyeti ve yüksek karlılık oranları elde edilmektedir. Bu hedefler tabii olarak her örgütün ulaşmak istediği sonuçlardır (Markos ve Sridevi, 2010: 90-92).

İşe angaje olma üç boyuttan oluşmaktadır. İşe angaje olmayı oluşturan boyutlar incelendiğinde; enerjik olma, çalışanın çalışma saatleri içerisinde kendini sürekli olarak dinç hissetmesi ve takım arkadaşları ile sürekli etkileşim 
içerisinde bulunma durumu; adanma, kişinin yaptığ 1 işe olan bağ 11 lı̆̆ını ifade etmektedir ve hatta bazen kişilerin kendilerini yaptıkları işleri ile bir bütün olarak görmeleri olarak belirtilmekte; özdeşleşme ise, kişinin yaptığı işin kendisinden ne istediğini bilme ve bu yetenekleri kendinde görme durumudur (Maslach ve diğerleri, 2001: 417; Schaufeli ve diğerleri, 2002). Kişinin "ben bu işi yapabilirim" diyebilmesi şeklinde de ifade edilebilir. Bu durumda yöneticilerin tükenmişliği veya kronik hale gelen yorgunluğu tersine çevirmeye yönelik bazı stratejiler geliştirmeleri ve işe angaje olan bireyler oluşturmaları gerekir (Crisp ve Chen, 2014: 953; Mordelet, 2013: 7).

\section{II. İş TATMiNi}

İş tatmini, yönetim literatüründe çok sayıda çalışmaya konu olmuştur. Çalışma yoğunluğunun çok fazla olmasına rağmen iş tatmini kavramının kesin sınırları belirlenmemiştir. Bunun nedeni ise iş tatmininin birçok faktörden etkilenme özelliğinin bulunmasıdır (Robbins ve Judge, 2012: 81). İş tatmini günümüzde her dönemden daha fazla üzerinde durulan bir alan haline gelmiştir ve örgütsel hayat üzerinde önemli etkilere sahiptir (Aziri, 2011: 84). Bir örgütteki insan kaynağı örgütün en değerli varlı̆̆ıdır ve sürdürülebilir bir hizmet sunumunun esasını oluşturur (Kumar ve diğerleri, 2013: 1). Teknolojik gelişim ve değişimin beraberinde getirdiği rekabet olgusu, örgütleri insan kaynaklarını en verimli şekilde değerlendirme yoluna götürmektedir (Kumar ve diğerleri, 2013: 1). Örgütün varlığını sürdürmesi ve gelişimi, verimliliği, karlılığ 1 vb. unsurlar insan kaynaklarına yönelik dikkatleri yoğunlaştırmış durumdadır (Chaulagain ve Khadka, 2012: 32).

İş tatmini, çalışanların yaptıkları işe atfettikleri olumlu ve olumsuz değerlere ilişkin tutumlardır. Çalışanların kendi işleri ile ilgili bir bütün olarak hisleri ve inançlarıdır. Çalışanların iş tatmininin yüksek olması, çalışanların duygusal ve zihinsel olarak iyi olduğunu gösterir. Kendini iyi hisseden ve bulunduğu örgüte bağl1lığ yüksek çalışanlar, örgütün hedefleri doğrultusunda daha fazla çalışırlar ve müşteri memnuniyetine oldukça önem verirler. $\mathrm{Bu}$ gelişmelere bağlı olarak iş tatmini konusu, yöneticilerin yönetmesi gereken en karmaşık alanlardan biri olarak ortaya çıkmaktadır (Aziri, 2011: 85). Bu süreçleri iyi yönetebilecek yöneticilerin iş tatmin düzeyleri yüksek bireyler olarak çalışanları yönlendirmeleri gerekir.

Örgütsel faktörler ve kötü çalışma koşulları, iş tatmini ile yakından ilişkilidir. Sağlık hizmetlerinin doğrudan insan hayatı ile ilişkili olmasından ötürü, kamu ve özel olarak sunulan bu hizmetlerde sağllk profesyonelleri sistemin temel taşlarından birini oluşturmaktadır (Kumar ve diğerleri, 2013: 2).

Toplumun sağl1k kurumundan beklentisi, sağlık hizmetinin sunumunda sağlık profesyonellerinin hastaların beklenti ve ihtiyaçlarına iyi bir performansla cevap vermesidir. Sağlı hizmetlerinin bir ekip hizmeti olmasından ötürü, hizmet zincirini oluşturan her bir birimin koordineli bir şekilde çalışması gerekir (Tengilimoğlu ve diğerleri, 2012: 78). Bu bağlantıları kurma ve devamını sağlama sağlık yöneticilerinin sorumluluğundadır. Dolayısıyla, sağlık hizmetlerinin sunumunda sağlık çalışanları arasında etkili bağlantılar oluşturulması böylelikle 
de daha çağdaş bir iş ortamının oluşturulmasında sağlık yöneticilerinin yeri oldukça önemlidir.

Bir çalışanın işinden duyduğu tatmin sadece işteki motivasyonunu etkilemekle kalmaz hayatındaki diğer önemli kararlara da etkide bulunabilir. Kişinin yaptığı işe bağlı olarak planladığı kariyer hedefleri göz önünde bulundurulduğunda, işinden duyduğu tatminin ne derece önemli olduğu anlaşılabilir. Sağlık hizmetleri profesyonellerinin iş tatmini sağlık hizmetinin kalitesini garantiye alan önemli bir faktördür (Chaulagain ve Khadka, 2012: 35; Aziri, 2011: 84).

İş tatminine ilişkin faktörler hijyen ve motive edici faktörler olarak ikiye ayrılmaktadır. Hijyen faktörler; örgüt politikası, denetim/kontrol, kişilerarası ilişkiler, çalışma koşulları, maaş, statü, iş güvenliği; motive edici faktörler ise; başarı, tanınma/takdir, yalnız çalışma, sorumluluk, terfi ve gelişimdir (Hyun, 2009: 9). İş tatmini konusunda hijyen ve motive edici faktörler önemlidir. Çünkü, çalışanların sadece hijyen veya motive edici faktörlerle tatmin edilmesi kimi zaman mümkün olmayabilir. Asıl önemli olan ise motive edici faktörlerin kullanılması ile çalışanların tatmin edilmesi yoluna gidilmesidir. Bu durumda da hastane yöneticilerinin önemi ortaya çıkmaktadır. Yöneticiler, hastane içerisinde hijyen ve motivasyon faktörlerini etkili bir şekilde kullanarak dengeyi sağlama yoluna gitmelidir (Paşamehmetoğlu ve Yeloğlu, 2013: 147).

Rekabetin yoğunlaştığı, teknolojinin hızla değişip geliştiği, hasta profilinin değiştiği, çalışan memnuniyetinin eskiye nazaran daha zor olduğu, hastanelerde yoğunluğun daha fazla olduğu, özelleşme eğilimleri vb. faktörler sağlık çalışanları üzerinde büyük baskı oluşturmaktadır (Will ve Powell, 2009: 267). Bu nedenle bu görevi üstlenen kişilerin yaptıkları işe ilişkin tatmin düzeylerinin yüksek olması gerekmektedir.

\section{YÖNTEM}

\section{A. Amaç ve Hipotezler}

$\mathrm{Bu}$ çalışmanın temel amacı, hekim ve hemşirelerin işe angaje olma ve iş tatmin düzeylerini belirlemek ve işe angaje olma ve iş tatmini arasındaki ilişkiyi araştırmaktır. Çalışma bu temel amaç dışında ayrıca çeşitli demografik değişkenler ile işe angaje olma ve iş tatmini arasındaki ilişkiyi tespit etmeyi amaçlamaktadır.

Araştırmada ileri sürülen hipotezler şunlardır:

$\mathbf{H}_{1}$ : İşe angaje olma ve iş tatmini arasında pozitif yönlü bir iliş̧ki vardır.

$\mathbf{H}_{2}$ : Çalışanların işe angaje olma düzeyi cinsiyetlerine göre farklılaşmaktadır.

$\mathbf{H}_{3}$ : Çalışanların iş tatmin düzeyi cinsiyetlerine göre farklılaşmaktadır.

$\mathbf{H}_{4}$ : Çalışanların işe angaje olma düzeyi medeni durumlarına göre farklılaşmaktadır

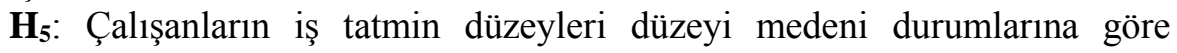
farklılaşmaktadır

$\mathbf{H}_{6}$ : Çalışanların işe angaje olma düzeyi mesleklerine göre farklılaşmaktadır

$\mathbf{H}_{7}$ : Çalışanların iş tatmin düzeyi mesleklerine göre farklılaşmaktadır 
H8: Çalışanların işe angaje olma düzeyi yaşlarına göre farklılaşmaktadır

H9: Çalışanların iş tatmin düzeyi yaşlarına göre farklılaşmaktadır

$\mathbf{H}_{10}$ : Çalışanların işe angaje olma düzeyi eğitim durumlarına göre farklılaşmaktadır

$\mathbf{H}_{11}$ : Çalışanların iş tatmin düzeyi eğitim durumlarına göre farklılaşmaktadır

$\mathbf{H}_{12}$ : Çalışanların işe angaje olma düzeyi meslekte çalışma sürelerine göre farklılaşmaktadır

$\mathbf{H}_{13}$ : Çalışanların iş tatmin düzeyi meslekte çalışma sürelerine göre farklılaşmaktadır

$\mathbf{H}_{14}$ : Çalışanların işe angaje olma düzeyi aylık gelirlerine göre farklılaşmaktadır

$\mathbf{H}_{15}$ : Çalışanların iş tatmin düzeyi aylık gelirlerine göre farklılaşmaktadır

B. Teknik ve Yöntem

Araştırma İzmir ilinde özel bir hastanede gerçekleştirilmiştir. Söz konusu hastanede görev yapan 50 hemşire ve 35 hekim araştırmanın evrenini oluşturmaktadır. Araştırma için Etik Kurul izni alınmış ve ardından söz konusu hastanede gönüllük esasına dayanarak anket çalışması gerçekleştirilmiştir. Yüz yüze anket yöntemi ile gerçekleştirilen alan araştırmasında 44 hemşire ve 16 hekim anket formunu cevaplamayı kabul etmiştir. Dolayısıyla toplam 60 adet anket formu elde edilmiştir. Elde edilen bu sayı evrenin \% 50'sinden fazla olduğundan örneklemin evreni temsil edebileceğine karar verilmiştir.

Araştırmada kullanılan veri toplama aracı üç bölümden oluşmaktadır. İlk bölüm katılımcıların demografik özelliklerini belirlemeye yönelik 7 sorudan oluşmaktadır. İkinci bölüm Schaufeli ve Bakker (2003)'in "İşe Angaje Olma" ölçeğinden oluşmaktadır. Söz konusu ölçek toplam 17 ifadeden oluşmaktadır. Ölçekte 6 ifade enerjik olma; 5 ifade adanma ve 6 ifade özdeşleşme boyutlarını araştırmaktadır. İşe Angaje Olma ölçeği 7'li Likert tipinde olup 0: Hiçbir zaman ve 6: Her zaman aralığında yanıtlanması istenmiştir. Üçüncü bölüm ise toplam 20 ifadeden oluşan "Minnesota İş Doyumu" ölçeğidir. İş tatminini araştıran ölçek 12 ifade ile içsel doyumu ve 8 ifade ile de dişsal doyumu araştırmaktadır. Ölçek 5'li Likert tipinde olup 1: Hiç memnun değilim, 5: Çok memnunum aralığında yanıtlanması istenmiştir. İşe angaje olma ölçeği için katılımcıların seçeneğe katılma düzeyinin aritmetik ortalaması 0-0,85 olduğunda "hiçbir zaman"; 0,861,71 olduğunda "neredeyse hiçbir zaman"; 1,72-2,57 olduğunda "nadiren"; 2,58 3,43 olduğunda "bazen"; 3,44-4,29 olduğunda "s1k s1k"; 4,30-5,15 olduğunda "çok sık" ve 5,16-6 olduğunda "her zaman" olarak yorumlanması kabul edilmiştir.

İş tatmini ölçeği için katılımcıların seçeneğe katılma düzeyinin aritmetik ortalamas1 1.00-1.79 olduğunda "hiç memnun değilim"; 1.80-2.59 olduğunda "memnun değilim"; 2.60-3.39 olduğunda "kısmen memnunum"; 3.40-4.19 olduğunda "memnunum" ve 4.20-5.00 olduğunda "çok memnunum" olarak yorumlanması kabul edilmiştir. 
Araştırmada elde edilen veriler, kodlanarak bilgisayara yüklenmiş ve SPSS 20.0 istatistik program ile analiz edilmiştir. Yapılan normallik testleri (Kolmogrov-Smirnov ve Shapiro-Wilk) sonucunda verilerin normal dağılım göstermediği anlaşılmış ve dolayısıyla parametrik olmayan testler kullanılmıştır. Analizlerde anlamlılık düzeyi $\mathrm{p}<0,05$ olarak kabul edilmiştir. Veriler yüzde (\%), frekans (f), aritmetik ortalama, Kruskal Wallis H, Mann Whitney U ve Spearman korelasyon analizleri ile incelenmiş̧ir. Kruskal Wallis $\mathrm{H}$ analizi neticesinde istatistiksel olarak anlamlı farklılık saptanan sorularda farklılığın hangi gruplar arasında ortaya çıktığı Kruskal Wallis 1-way Anova ile araştırılmıştır.

\section{BULGULAR}

Araştırmada kullanılan ölçeklerin geçerliği, kullanılmakta olan geçerlik yöntemlerinden biri olan ve ölçeğin bir yapıyı ölçüp ölçmediğinin bilimsel bir topluluk tarafından değerlendirildiği bir yöntem olan "yüz görünüm geçerliği”" kullanılarak araştırılmıştır (Neuman (2014: 216). İşe angaje olma ve iş tatmini ölçeklerinin ölçmek istedikleri yapıyı gerçekten ölçüp ölçmediklerini belirlemek amacıyla örgütsel davranış alanında bilimsel çalışmaları bulunan alanında uzman 10 kişiden görüş alınmıştır. Uzman kişilerin değerlendirmeleri sonucu söz konusu ölçüm araçlarının geçerli olduğu anlaşılmıştır.

Araştırmada kullanılan ölçeklerin güvenilirliklerinin belirlenmesinde Cronbach Alfa $(\alpha)$ katsayısı kullanılmıştır.

İşe angaje olma ölçeğinin Cronbach Alfa $(\alpha=0,922)$ değeri ölçeğin yüksek düzeyde güvenilir olduğunu göstermektedir. Aynı şekilde, ölçeğin enerjik olma $(\alpha=0,832)$, adanma $(\alpha=0,815)$ ve özdeşleşme $(\alpha=0,799)$ alt boyutlarına ilişkin Cronbach Alfa değerleri söz konusu ölçeklerin oldukça güvenilir olduğunu ortaya koymaktadır. Ölçeklere ilişkin genel ortalamalar incelendiğinde ise katılımcıların işe angaje olma düzeylerinin yüksek ( $\bar{X}=4,38$ ) olduğu saptanmıştır. Adanma ( $\bar{X}=4,74)$ boyutunun yüksek ve enerjik olma $(\bar{X}=4,28)$ ile özdeşleşme $(\bar{X}=$ 4,18 ) boyutlarının ise orta düzeyde olduğu tespit edilmiştir. İş tatmini ölçeğinin Cronbach Alfa $(\alpha=0,923)$ değeri ölçeğin yüksek düzeyde güvenilir olduğunu göstermektedir. Ölçeğin içsel doyum $(\alpha=0,882)$ ve dişsal doyum $(\alpha=0,838)$ boyutlarına ilişkin Cronbach Alfa değerleri ölçeklerin güvenilir olduğunu göstermektedir. Ölçeklere ilişkin genel ortalamalar incelendiğinde ise katılımcıların iş tatmini $(\bar{X}=3,74)$ düzeylerinin, içsel doyum $\left(\bar{X}_{=3,91)}\right.$ ve dışsal doyum ( $\bar{X}=3,49$ ) düzeylerinin yüksek olduğu saptanmıştır.

\section{A. Demografik Özelliklere İlişskin Bulgular}

Katılımcıların demografik özelliklerine ilişkin bulgular aşağıda özetlenmiştir. Katılımcıların \% 60'ı (36 kişi) kadın, \% 40’1 (24 kişi) erkektir ve \%40'ı evli (24 kişi) ve \%60'ı (36 kişi) ise bekârdır. Katılımcıların yaş dağılımı incelendiğinde çoğunluğun (\%65, 39 kişi) gençlerden oluştuğu (20-29 yaş aralığı) görülmektedir. Eğitim durumu dikkate alındığında ise lise (26 kişi, \%43,3) ve üniversite (20 kişi, \%33,3) mezunları genel olarak çoğunluktadır. Katılımcıların çoğunluğunun (33 kişi, \%55) aylık geliri $2500 \mathrm{TL}$ ve daha az iken meslekte 
çalışma süreleri (36 kişi, \%60) 1 ile 5 yıl arasıdır. Aylık gelir ve çalışma süresi birlikte değerlendirildiğinde sonuçlar birbiriyle tutarlıdır. Katılımcıların \%73,3’ü (44 kişi) hemşiredir ve \%26,7’si (16 kişi) doktordur.

İşe angaje olma ve boyutlarına ilişkin ortalama ve standart sapmaya ilişkin bulgular aşağıda özetlenmiştir.

Tablo 1. İşe Angaje Olma ve Boyutlarına İlişkin Ortalama ve Standart Sapmalar

\begin{tabular}{|c|c|c|c|c|}
\hline & İfadeler & $\mathbf{n}$ & $\bar{X}$ & S.S. \\
\hline \multirow{6}{*}{ 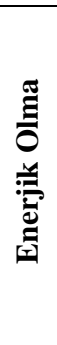 } & İşimde kendimi enerji dolu hissederim & 60 & 4,28 & 1,26 \\
\hline & İşimde kendimi canlı ve güçlü hissederim & 60 & 4,30 & 1,28 \\
\hline & Sabah kalktığımda işe gitmeye istekli olurum & 60 & 3,68 & 1,48 \\
\hline & Çok uzun süre çalışmaya devam edebilirim & 60 & 4,50 & 1,26 \\
\hline & İşimde zihinsel olarak oldukça dayanıklıyım & 60 & 4,58 & 1,28 \\
\hline & $\begin{array}{l}\text { İşler yolunda gitmediği zamanlarda bile kararlı davranışımı } \\
\text { sürdürürüm }\end{array}$ & 60 & 4,32 & 1,30 \\
\hline \multirow{5}{*}{ 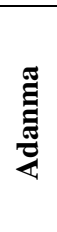 } & Yaptığım işin amaç ve anlamı vardır & 60 & 5,47 &, 85 \\
\hline & İşim bana heyecan verir & 60 & 4,28 & 1,40 \\
\hline & İşim bana ilham verir & 60 & 4,12 & 1,45 \\
\hline & Yaptığım işle gurur duyarım & 60 & 5,25 & 1,24 \\
\hline & İşim benim için gelişim firsatları ile doludur & 60 & 4,57 & 1,31 \\
\hline \multirow{6}{*}{ 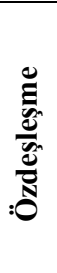 } & Çalışırken zamanın nasıl geçtiğini fark etmem & 60 & 4,37 & 1,15 \\
\hline & Çalışırken etrafımdaki her şeyi unuturum & 60 & 3,93 & 1,46 \\
\hline & Yoğun tempoda çalıştığımda kendimi mutlu hissederim & 60 & 3,83 & 1,44 \\
\hline & Çalışırken adeta işime gömülürüm & 60 & 4,65 & 1,16 \\
\hline & Çalışırken kendimi işime kaptırırım & 60 & 4,53 & 1,10 \\
\hline & Kendimi işe çok kaptırdığım için işten kopmakta zorlanırım & 60 & 3,78 & 1,25 \\
\hline
\end{tabular}

Katılımcıların işe angaje olma düzeylerinin yüksek olduğu Tablo 1'den anlaşılmaktadır. Boyutların ortalamalarına bakıldığında her bir boyutun ortalamasının ( $\bar{X}$ ) 3.44'ten büyük olduğu görülebilmektedir. Bu durum, katılımcıların oldukça yüksek işe angaje olma düzeyine sahip olduğu anlamına gelmektedir. İşe angaje olmanın tüm boyutlarında aynı şekilde olumlu yöndeki eğilim anlaşılabilir. Hekim ve hemşirelerin genelinde enerjik olma, adanma ve özdeşleşmenin oldukça yüksek olduğu söylenebilir.

İşe tatmini ve boyutlarına ilişkin ortalama ve standart sapmaya ilişkin bulgular aşağıda özetlenmiştir. 
Tablo 2. İş Tatmini ve Boyutlarına İlişkin Ortalama ve Standart Sapmalar

\begin{tabular}{|c|c|c|c|c|}
\hline & İfadeler & $\mathbf{n}$ & $\overline{\mathrm{X}}$ & S.S. \\
\hline \multirow{12}{*}{ 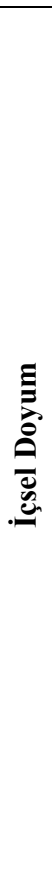 } & Beni her zaman meşgul etmesi bakımından & 60 & 3,68 & ,72 \\
\hline & Tek başıma çalışma olanağımın olması bakımından & 60 & 3,40 & 1,20 \\
\hline & Ara sıra değişik şeyler yapabilme şansım olması bakımından & 60 & 3,47 & 1,02 \\
\hline & $\begin{array}{l}\text { Toplumda "saygın bir kişi” olma şansını bana vermesi } \\
\text { bakımından }\end{array}$ & 60 & 4,13 & 1,07 \\
\hline & $\begin{array}{l}\text { Vicdanıma aykırı olmayan şeyler yapabilme şansımın olması } \\
\text { bakımından }\end{array}$ & 60 & 3,93 & 1,19 \\
\hline & Bana sabit bir iş sağlaması bakımından & 60 & 4,22 & ,83 \\
\hline & $\begin{array}{l}\text { Başkaları için bir şeyler yapabilme olanağına sahip olmam } \\
\text { bakımından }\end{array}$ & 60 & 4,50 & 60 \\
\hline & 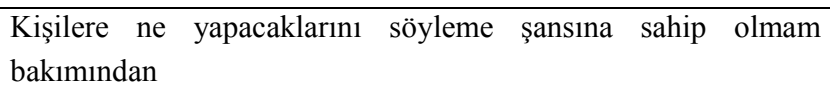 & 60 & 3,95 & ,98 \\
\hline & $\begin{array}{l}\text { Kendi yeteneklerimi kullanarak bir şeyler yapabilme şansımın } \\
\text { olması bakımından }\end{array}$ & 60 & 4,17 & ,83 \\
\hline & 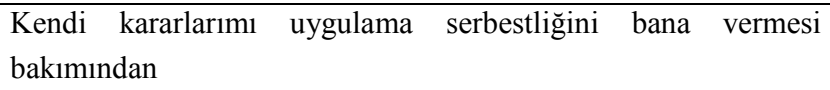 & 60 & 3,60 & 1,17 \\
\hline & $\begin{array}{l}\text { İşimi yaparken kendi yöntemlerimi kullanabilme şansını bana } \\
\text { sağlaması bakımından }\end{array}$ & 60 & 3,78 & ,99 \\
\hline & Yaptığım iş karşılığında duyduğum başarı hissi bakımından & 60 & 4,08 & 1,06 \\
\hline \multirow{8}{*}{ 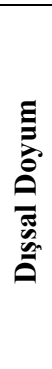 } & Yöneticimin, ekibindeki kişileri yönetme tarzı bakımından & 60 & 3,80 & 1,13 \\
\hline & Yöneticimin, karar vermedeki yeteneği bakımından & 60 & 3,72 & 1,14 \\
\hline & İş ile ilgili alınan kararların uygulanmaya konması bakımından & 60 & 3,70 & 1,09 \\
\hline & Yaptığım iş karşılığında aldığım ücret bakımından & 60 & 3,13 & 1,31 \\
\hline & İş içinde terfi olanağımın olması bakımından & 60 & 3,27 & 1,16 \\
\hline & Çalışma şartları bakımından & 60 & 3,28 & 1,14 \\
\hline & Çalışma arkadaşlarımın birbirleri ile anlaşmaları bakımından & 60 & 3,65 & 1,22 \\
\hline & Yaptığım iyi bir iş karşılığında takdir edilmem bakımından & 60 & 3,38 & 1,18 \\
\hline
\end{tabular}

Genel olarak ortalamalara bakıldığında katılımcıların iş tatmin düzeylerinin yüksek olduğu anlaşılmaktadır ( $\bar{X}>2.60$ ). İçsel doyum boyutunda katılımcıların iş tatmin düzeylerinin daha yüksek olduğu görülmekte ve katılımcilar memnun olduklarını ifade etmiştir ( $\bar{X}_{>} 3.40$ ). Dışsal doyum boyutunda 4 boyuta ilişkin ortalamaların 3.39'dan düşük olduğu görülmektedir. Bu durum katılımcıların ilgili boyutlara ilişkin kısmen memnun oldukları anlamına gelmektedir.

\section{B. Hipotez Testleri}

İșe angaje olma, alt boyutları, iş tatmini ve alt boyutlarına yönelik tutumun cinsiyete göre farklılaşıp farklılaşmadığ 1 Mann Whitney U testi ile araştırılmıştır ve sonuçlar Tablo 3'te özetlenmiştir. 
Tablo 3. İşe Angaje Olma ve İş Tatmini İle Cinsiyet Arasındaki İlişki

\begin{tabular}{|c|c|c|c|c|c|c|}
\hline & Cinsiyet & $\mathbf{N}$ & Sira Ort. & $\mathbf{U}$ & $\mathbf{Z}$ & $\mathbf{P}$ \\
\hline \multirow{2}{*}{$\begin{array}{l}\text { İse Angaje } \\
\text { Olma }\end{array}$} & Kadın & 36 & 25,03 & \multirow[b]{2}{*}{235,000} & \multirow[b]{2}{*}{$-2,974$} & \multirow[b]{2}{*}{0,003} \\
\hline & Erkek & 24 & 38,71 & & & \\
\hline \multirow{2}{*}{ İş Tatmini } & Kadın & 36 & 25,04 & \multirow{2}{*}{235,500} & \multirow{2}{*}{$-2,967$} & \multirow{2}{*}{,003 } \\
\hline & Erkek & 24 & 38,69 & & & \\
\hline \multirow{2}{*}{$\begin{array}{c}\text { Enerjik } \\
\text { Olma }\end{array}$} & Kadın & 36 & 24,17 & \multirow{2}{*}{204,000} & \multirow{2}{*}{$-3,450$} & \multirow{2}{*}{, 001} \\
\hline & Erkek & 24 & 40,00 & & & \\
\hline \multirow{2}{*}{ Adanma } & Kadın & 36 & 25,90 & \multirow{2}{*}{266,500} & \multirow{2}{*}{$-2,504$} & \multirow{2}{*}{, 012} \\
\hline & Erkek & 24 & 37,40 & & & \\
\hline \multirow{2}{*}{ Özdeşleşme } & Kadın & 36 & 26,33 & \multirow{2}{*}{282,000} & \multirow{2}{*}{$-2,269$} & \multirow{2}{*}{, 023} \\
\hline & Erkek & 24 & 36,75 & & & \\
\hline \multirow{2}{*}{ İçsel Tatmin } & Kadın & 36 & 24,96 & \multirow{2}{*}{232,500} & \multirow{2}{*}{$-3,019$} & \multirow{2}{*}{, 003} \\
\hline & Erkek & 24 & 38,81 & & & \\
\hline \multirow{2}{*}{$\begin{array}{c}\text { Dişsal } \\
\text { Tatmin }\end{array}$} & Kadın & 36 & 25,90 & \multirow{2}{*}{266,500} & \multirow{2}{*}{$-2,505$} & \multirow{2}{*}{,012 } \\
\hline & Erkek & 24 & 37,40 & & & \\
\hline
\end{tabular}

Analiz neticesinde tüm değişkenlere yönelik tutumun cinsiyete göre istatistiksel olarak anlamlı biçimde farklılaştı̆̆ saptanmıştır. Buna göre erkekler kadinlardan daha fazla işe angaje olmuş $(U=235,000 ; z=-2,974 ; p=, 003, p<, 05)$ durumdadır ve aynı şekilde daha yüksek düzeyde iş tatminine $(\mathrm{U}=235,500$; $\mathrm{z}=$ 2,967; $\mathrm{p}=, 003, \mathrm{p}<, 05)$ sahiptir. Sira ortalamaları dikkate alındığında erkekler kadinlardan daha fazla enerjik hissetmekte $(U=204,000 ; z=-3,450 ; p=, 001$, $\mathrm{p}<, 05)$; daha fazla adanmışl1k $(\mathrm{U}=266,500 ; \mathrm{z}=-2,504 ; \mathrm{p}=, 012, \mathrm{p}<, 05)$ hissetmekte; daha fazla özdeşleşme ( $\mathrm{U}=282,000 ; \mathrm{z}=-2,269 ; \mathrm{p}=, 023, \mathrm{p}<, 05)$ yaşamakta; daha fazla içsel tatmin $(\mathrm{U}=232,500 ; \mathrm{z}=-3,019 ; \mathrm{p}=, 003, \mathrm{p}<, 05)$ ve daha fazla dişsal tatmin $(U=266,500 ;-2,505 ; p=, 012, p<, 05)$ duymaktadir.

İşe angaje olma, alt boyutları, iş tatmini ve alt boyutlarına yönelik tutumun medeni duruma göre farklılaşıp farklılaşmadığı Mann Whitney $U$ testi ile araştırılmıştır ve sonuçlar Tablo 4'te özetlenmiştir.

Tablo 4. İşe Angaje Olma ve İş Tatmini İle Medeni Durum Arasındaki İlişki

\begin{tabular}{|c|c|c|c|c|c|c|}
\hline & $\begin{array}{l}\text { Medeni } \\
\text { Durum }\end{array}$ & $\mathbf{N}$ & Sira Ort. & $\mathbf{U}$ & $\mathbf{Z}$ & $\mathbf{P}$ \\
\hline \multirow{2}{*}{ İş Tatmini } & Evli & 24 & 36,52 & \multirow{2}{*}{287,500} & \multirow{2}{*}{$-2,182$} & \multirow{2}{*}{, 029} \\
\hline & Bekâr & 36 & 26,49 & & & \\
\hline \multirow{2}{*}{ İçsel Tatmin } & Evli & 24 & 36,94 & \multirow{2}{*}{277,500} & \multirow{2}{*}{$-2,338$} & \multirow{2}{*}{, 019} \\
\hline & Bekâr & 36 & 26,21 & & & \\
\hline \multirow{2}{*}{$\begin{array}{c}\text { Dişsal } \\
\text { Tatmin }\end{array}$} & Evli & 24 & 36,21 & \multirow{2}{*}{295,000} & \multirow{2}{*}{$-2,074$} & \multirow{2}{*}{,038 } \\
\hline & Bekâr & 36 & 26,69 & & & \\
\hline
\end{tabular}

Analiz sonucuna göre iş tatmini, içsel ve dişsal tatmine ilişkin görüşler medeni duruma göre istatistiksel olarak anlamlı biçimde farklılaşmaktadır. Sıra 
ortalamaları incelendiğinde, evliler bekârlardan daha fazla iş tatmini (U=287,500; $\mathrm{z}=-2,182 ; \mathrm{p}=, 029, \mathrm{p}<, 05)$ hissetmekte; daha fazla içsel tatmin $(\mathrm{U}=277,500 ; \mathrm{z}=$ $2,338 ; \mathrm{p}=, 019, \mathrm{p}<, 05)$ ve daha fazla dişsal tatmin $(\mathrm{U}=295,000 ; \mathrm{z}=-2,074 ; \mathrm{p}=, 038$, $\mathrm{p}<, 05)$ duymaktadır. Katılımcıların işe angaje olma, enerjik olma, adanma ve özdeşleşme konularındaki görüşleri medeni durumlarına göre farklılaşmamaktadır.

İşe angaje olma, alt boyutları, iş tatmini ve alt boyutlarına yönelik tutumun mesleğe göre farklılaşıp farklılaşmadığı Mann Whitney U testi ile araştırılmıştır ve sonuçlar Tablo 5 'te özetlenmiştir.

Tablo 5. İşe Angaje Olma ve İş Tatmini İle Meslek Arasındaki İlişki

\begin{tabular}{cllcccc}
\hline & Meslek & $\mathbf{N}$ & Sıra Ort. & $\mathbf{U}$ & $\mathbf{Z}$ & P \\
\hline \multirow{2}{*}{ İş Tatmini } & Hemşire & 44 & 27,28 & \multirow{2}{*}{210,500} & $-2,367$ & \multirow{2}{*}{018} \\
\cline { 2 - 4 } & Hekim & 16 & 39,34 & & & \\
\hline $\begin{array}{c}\text { İçsel } \\
\text { Tatmin }\end{array}$ & Hemşire & 44 & 26,66 & \multirow{2}{*}{183,000} & $-2,833$ & \multirow{2}{*}{005} \\
\cline { 2 - 4 } & Hekim & 16 & 41,06 & & & \\
\hline
\end{tabular}

Katılımcıların iş tatmini ve içsel tatmine ilişkin görüşleri mesleklerine göre istatistiksel olarak anlamlı biçimde farklılaşmaktadır. Sıra ortalamaları incelendiğinde, hekimler hemşirelere göre daha fazla iş tatmini $(U=210,500 ; z=-$ $2,367 ; \mathrm{p}=, 018, \mathrm{p}<, 05)$ ve daha fazla içsel tatmin $(\mathrm{U}=183,000 ; \mathrm{z}=-2,833 ; \mathrm{p}=, 005$, $\mathrm{p}<, 05)$ duymaktadır. Katılımcıların işe angaje olma, enerjik olma, adanma, özdeşleşme ve dışsal tatmin konularındaki görüşleri mesleklerine göre farklılaşmamaktadır.

İşe angaje olma, alt boyutları, iş tatmini ve alt boyutlarına yönelik tutumun katılımcıların yaşlarına göre farklılaşıp farklılaşmadığı Kruskal Wallis H testi ile araştırılmıştır ve sonuçlar Tablo 6'da özetlenmiştir.

Tablo 6. İşe Angaje Olma ve İş Tatmini İle Yaş Arasındaki İlişki

\begin{tabular}{|c|c|c|c|c|c|c|}
\hline & Yaş & $\mathbf{N}$ & Sira Ort. & SD & $\chi^{2}$ & $\mathbf{P}$ \\
\hline \multirow{3}{*}{ İş Tatmini } & $20-29$ & 39 & 25,49 & \multirow{3}{*}{2} & \multirow{3}{*}{10,051} & \multirow{3}{*}{,007 } \\
\hline & $30-39$ & 8 & 35,31 & & & \\
\hline & 40 ve üzeri & 13 & 42,58 & & & \\
\hline \multirow{3}{*}{ Özdeşleşme } & $20-29$ & 39 & 25,69 & \multirow{3}{*}{2} & \multirow{3}{*}{8,502} & \multirow{3}{*}{, 014} \\
\hline & $30-39$ & 8 & 40,06 & & & \\
\hline & 40 ve üzeri & 13 & 39,04 & & & \\
\hline \multirow{3}{*}{ İçsel Tatmin } & $20-29$ & 39 & 24,97 & \multirow{3}{*}{2} & \multirow{3}{*}{12,341} & \multirow{3}{*}{, 002} \\
\hline & $30-39$ & 8 & 35,63 & & & \\
\hline & 40 ve üzeri & 13 & 43,92 & & & \\
\hline \multirow{3}{*}{$\begin{array}{c}\text { Dişsal } \\
\text { Tatmin }\end{array}$} & $20-29$ & 39 & 26,53 & \multirow{3}{*}{2} & \multirow{3}{*}{6,581} & \multirow{3}{*}{037} \\
\hline & $30-39$ & 8 & 33,63 & & & \\
\hline & 40 ve üzeri & 13 & 40,50 & & & \\
\hline
\end{tabular}


Analiz sonucuna göre iş tatmini yaşa göre farklılaşmaktadır $(\mathrm{sd}=2$; $\chi 2=10,051 ; \mathrm{p}=, 007, \mathrm{p}<, 05)$ ve farkl1lığın hangi gruplar arasında gerçekleştiği incelendiğinde ise 40 ve üzeri yaştaki katılımcıların 20-29 yaş aralığındaki katılımcılara göre daha yüksek iş tatminine sahip oldukları $(\mathrm{p}=, 007)$ saptanmıştır. İçsel tatminin yaşa göre farklılaştığ $(\mathrm{sd}=2 ; \chi 2=12,341 ; \mathrm{p}=, 002, \mathrm{p}<, 05)$ ve 40 ve üzeri yaştaki katılımcıların 20-29 yaş aralığındaki katılımcılara göre daha yüksek içsel tatmine sahip oldukları $(p=, 002)$ tespit edilmiştir. Benzer biçimde dışsal tatminin yaşa göre farklılaştığ $1(\mathrm{sd}=2 ; \chi 2=6,581 ; \mathrm{p}=, 037, \mathrm{p}<, 05)$ ve 40 ve üzeri yaştaki katılımcıların 20-29 yaş aralığındaki katılımcılara göre daha yüksek dışsal tatmine sahip oldukları $(\mathrm{p}=, 037)$ ortaya konmuştur. Özdeşleşme konusunda da yaşa göre farklılaşma olduğu $(\mathrm{sd}=2 ; \chi 2=8,502 ; \mathrm{p}=, 014, \mathrm{p}<, 05)$ saptanmıştır. S1ra ortalamaları incelendiğinde 30-39 yaş aralığındaki katılımcıların diğer katılımcılara göre daha olumlu görüş bildirdiği; bu konuda 20-29 yaş aralığındaki katılımcıların ise en olumsuz görüşe sahip olduğu tespit edilmiştir. Katılımcıların işe angaje olma, enerjik olma ve adanma konularındaki görüşleri yaşlarına göre farklılaşmamaktadır.

İşe angaje olma, alt boyutları, iş tatmini ve alt boyutlarına yönelik tutumun katılımcıların eğitim durumuna göre farklılaşıp farklılaşmadığı Kruskal Wallis H testi ile araştırılmıştır ve sonuçlar Tablo 7'de özetlenmiştir.

Tablo 7. İşe Angaje Olma ve İş Tatmini İle Eğitim Durumu Arasındaki İlişki

\begin{tabular}{|c|c|c|c|c|c|c|}
\hline & $\begin{array}{l}\text { Ĕgitim } \\
\text { Durumu }\end{array}$ & $\mathbf{N}$ & Sira Ort. & SD & $\chi^{2}$ & $\mathbf{P}$ \\
\hline \multirow{3}{*}{ İş Tatmini } & Lise & 26 & 30,77 & \multirow{3}{*}{2} & \multirow{3}{*}{6,998} & \multirow{3}{*}{,030 } \\
\hline & Üniversite & 20 & 23,68 & & & \\
\hline & Lisansüstü & 14 & 39,75 & & & \\
\hline \multirow{3}{*}{$\begin{array}{c}\text { İçsel } \\
\text { Tatmin }\end{array}$} & Lise & 26 & 29,15 & \multirow{3}{*}{2} & \multirow{3}{*}{10,470} & \multirow{3}{*}{, 005} \\
\hline & Üniversite & 20 & 23,55 & & & \\
\hline & Lisansüstü & 14 & 42,93 & & & \\
\hline
\end{tabular}

Katılımcıların iş tatmini ( $\left.\mathrm{sd}=2 ; \chi^{2}=6,998 ; \mathrm{p}=, 030, \mathrm{p}<, 05\right)$ ve içsel tatmine $\left(\mathrm{sd}=2 ; \chi^{2}=10,470 ; \mathrm{p}=, 005, \mathrm{p}<, 05\right)$ ilişkin görüşlerinin eğitim durumlarına göre farklılaştı̆g saptanmıştır. İş tatmini konusunda eğitim düzeyi lisansüstü olan katılımcılar eğitim düzeyi lisans olan katılımcılardan daha olumlu $(p=, 025)$ görüş bildirmiştir. Benzer biçimde içsel tatmin konusunda da eğitim düzeyi lisansüstü olan katılımcılar eğitim düzeyi lisans olan katılımcılardan daha olumlu $(p=, 004)$ görüş bildirmiştir. Dolayısıyla bu konularda lisans ve lisansüstü mezunu olanlar arasında bir görüş farklılı̆̆ söz konusudur. Katılımcıların işe angaje olma, enerjik olma, adanma, özdeşleşme ve dışsal tatmin konularındaki görüşleri eğitim durumlarına göre farklılaşmamaktadır. 
İşe angaje olma, alt boyutları, iş tatmini ve alt boyutlarına yönelik tutumun katılımcıların mesleklerinde çalışma sürelerine göre farklılaşıp farklılaşmadığ 1 Kruskal Wallis H testi ile araştırılmıştır ve sonuçlar Tablo 8'de özetlenmiştir.

Tablo 8. İşe Angaje Olma ve İş Tatmini İle Kıdem Arasındaki İlişki

\begin{tabular}{|c|c|c|c|c|c|c|}
\hline & Çalışma Süresi & $\mathbf{N}$ & Sira Ort. & SD & $\chi^{2}$ & $\mathbf{P}$ \\
\hline \multirow{3}{*}{ Özdeşleşme } & $1-5 \mathrm{y} 1 \mathrm{l}$ & 36 & 25,82 & \multirow{3}{*}{2} & \multirow{3}{*}{6,496} & \multirow{3}{*}{,039 } \\
\hline & 6-10 y1l & 6 & 37,33 & & & \\
\hline & 11 y1l ve üzeri & 18 & 37,58 & & & \\
\hline \multirow{3}{*}{ İçsel Tatmin } & $1-5$ y1l & 36 & 26,03 & \multirow{3}{*}{2} & \multirow{3}{*}{7,305} & \multirow{3}{*}{,026 } \\
\hline & 6-10 y1l & 6 & 30,00 & & & \\
\hline & 11 yıl ve üzeri & 18 & 39,61 & & & \\
\hline
\end{tabular}

Katılımcıların içsel tatmine ilişkin görüşleri mesleki kıdemlerine göre farklılaşmaktadır $(\mathrm{sd}=2 ; \chi 2=7,305 ; \mathrm{p}=, 026, \mathrm{p}<, 05)$ ve bu farklılık $1-5$ y1l aras1 çalışanlar ile 11 yıl ve daha fazla süredir çalışanlar arasında ortaya çıkmaktadır. 11 yıl ve daha fazla süredir çalışanlar 1-5 yıl arası çalışanlara göre bu konuda daha olumlu $(\mathrm{p}=, 021)$ görüşe sahiptir. Katılımcıların özdeşleşmeye ilişkin görüşleri de mesleki kıdemlerine göre farklılaşmaktadır ( $\mathrm{sd}=2 ; \chi 2=6,496 ; \mathrm{p}=, 039$, $\mathrm{p}<, 05)$. Sıra ortalamaları incelendiğinde 11 yıl ve daha fazla süredir çalışanların özdeşleşme konusunda diğer katılımcılara göre daha olumlu görüş bildirdiği; 1-5 yıl arası çalışanların bu konuda en olumsuz görüşe sahip olduğu saptanmıştır. Katılımcıların işe angaje olma, iş tatmini, enerjik olma, adanma ve dışsal tatmin konularındaki görüşleri mesleklerinde çalışma sürelerine göre farklılaşmamaktadır.

İşe angaje olma, alt boyutları, iş tatmini ve alt boyutlarına yönelik tutumun katılımcıların aylık gelirlerine göre farklılaşıp farklılaşmadığı Kruskal Wallis H testi ile araştırılmıştır ve sonuçlar Tablo 9'da özetlenmiştir.

Tablo 9. İşe Angaje Olma ve İş Tatmini İle Gelir Arasındaki İlişki

\begin{tabular}{|c|c|c|c|c|c|c|}
\hline & Gelir & $\mathbf{N}$ & Sira Ort. & SD & $\chi^{2}$ & $\mathbf{P}$ \\
\hline \multirow{3}{*}{ İş Tatmini } & $\begin{array}{l}2500 \text { TL ve daha } \\
a z\end{array}$ & 33 & 25,77 & \multirow{3}{*}{2} & \multirow{3}{*}{6,063} & \multirow{3}{*}{,048 } \\
\hline & $2501-3500 \mathrm{TL}$ & 8 & 32,00 & & & \\
\hline & 3501 TL ve üzeri & 19 & 38,08 & & & \\
\hline \multirow{3}{*}{ İçsel Tatmin } & $\begin{array}{l}2500 \text { TL ve daha } \\
\text { az }\end{array}$ & 33 & 25,48 & \multirow{3}{*}{2} & \multirow{3}{*}{7,350} & \multirow{3}{*}{,025 } \\
\hline & $2501-3500 \mathrm{TL}$ & 8 & 30,81 & & & \\
\hline & 3501 TL ve üzeri & 19 & 39,08 & & & \\
\hline
\end{tabular}

Katılımcıların iş tatminine ilişkin görüşleri aylık gelirlerine göre farklılaşmaktadır ( $\left.\mathrm{sd}=2 ; \chi^{2}=6,063 ; \mathrm{p}=, 048, \mathrm{p}<, 05\right)$, aylık $3501 \mathrm{TL}$ ve üzeri gelire 
sahip kat1lımc1lar 2500 TL ve daha az gelire sahip katılımcılara göre daha yüksek iş tatminine sahiptir $(\mathrm{p}=, 043)$. Katılımcıların içsel tatmine yönelik görüşleri de aylık gelirlerine göre farklılaşmaktadır $(\mathrm{sd}=2 ; \chi 2=7,350 ; \mathrm{p}=, 025, \mathrm{p}<, 05)$, aylık 3501 TL ve üzeri gelire sahip katılımcilar 2500 TL ve daha az gelire sahip katılımcılara göre daha yüksek içsel tatmin yaşamaktadır $(\mathrm{p}=, 020)$. Katılımcıların işe angaje olma, enerjik olma, adanma, özdeşleşme ve dışsal tatmin konularındaki görüşleri aylık gelirlerine göre farklılaşmamaktadır.

İş tatmini ile işe angaje olma arasında bir ilişki olup olmadığ ${ }_{1}$ alt boyutlarıyla birlikte Spearman Sıra Korelasyonu kullanılarak araştırılmıştır. Korelasyon analizi sonuçları Tablo 10'da gösterilmiştir.

Tablo 10. Korelasyon Analizi Sonuçları

\begin{tabular}{|c|c|c|c|}
\hline \multicolumn{2}{|c|}{ angaje olma } & iş tatmini \\
\hline Spearman's rho olma & Correlation Coefficient & 1,000 &, $634^{* *}$ \\
\hline & Sig. (2-tailed) & &, 000 \\
\hline & $\mathrm{N}$ & 60 & 60 \\
\hline iş tatmini & Correlation Coefficient &, $634^{* *}$ & 1,000 \\
\hline & Sig. (2-tailed) &, 000 & \\
\hline & $\mathrm{N}$ & 60 & 60 \\
\hline
\end{tabular}

${ }^{\star *}$ Korelasyon 0,01 önemlilik düzeyinde anlamlıdır.

Korelasyon analizi sonucuna göre işe angaje olma ve iş tatmini arasında pozitif yönlü ve orta düzeyde $(r=, 634 ; p=, 000, p<, 05)$ bir ilişki vardır. Hekim ve hemşirelerin işe angaje olma düzeyi arttıkça iş tatmin düzeyinin; iş tatmin düzeyi arttıkça da işe angaje olma düzeyinin de arttığı saptanmıştır.

\section{SONUÇ}

$\mathrm{Bu}$ çalışmada hekim ve hemşirelerin işe angaje olma ve iş tatmin düzeyleri, işe angaje olma ve iş tatmini arasındaki ilişki araştırılmıştır. Çalışmada bu temel amaç dışında ayrıca çeşitli demografik değişkenler ile işe angaje olma ve iş tatmini arasındaki ilişkide araştırılmıştır. Yüz yüze anket yönteminin kullanıldığı bu çalışmada 44 hemşire ve 16 doktora anket yapılmıştır.

Hekim ve hemşirelerin işe angaje olma ve iş tatmin düzeylerininyüksek olduğu anlaşılmıştır. Bu durum hekim ve hemşirelerin özel hastanede çalışıyor olmaları ile açıklanabilir. Özel hastanelerde çalışma yoğunluğunun daha fazla ve buna bağlı olarak daha yüksek performans beklentisinin olması sağlık çalışanları üzerinde oldukça etkilidir. Ayrıca söz konusu sağlik hizmetleri olduğu için mesleğin doğası gereği işe angaje olma hususu sağlık çalışanlarından genel olarak beklenmektedir. 
Spearman's rho korelasyon analizi neticesinde işe angaje olma ve iş tatmin düzeyi arasından pozitif yönlü anlamlı bir ilişki olduğu anlaşılmıştır. Bu nedenle $\mathbf{H}_{1}$ kabul edilmiştir. Bu durum, hekim ve hemşirelerin işe angaje olma düzeyleri arttıkça iş tatmin düzeylerinin de arttığ 1 anlamına gelmektedir. İşinde kendini enerjik hisseden, işine adanan ve işiyle özdeşleşen bir kişinin aynı zamanda işinden duyduğu içsel ve dişsal tatmin düzeyinin de yüksek olacağı anlamına gelmektedir. Durumun tersi de aynı şekilde geçerlidir.

İşe angaje olma ve iş tatmin düzeyi bağlamında kadın ve erkekler arasında anlamlı bir farklılık tespit edilmiştir.Dolayısıyla $\mathbf{H}_{\mathbf{2}}$ ve $\mathbf{H}_{\mathbf{3}}$ kabul edilmiştir. Erkeklerin kadınlardan daha fazla işine angaje olduğu ve yaptıkları işten daha fazla memnuniyet duydukları belirlenmiştir. Katılımcıları oluşturan erkeklerin çoğunluğu alanında uzman hekimlerden oluşmaktadır. Özel hastanede çalışıyor olmaları, yaş ortalamalarının ve aldıkları ücretlerin yüksek olması bu durum ile yakından ilişkilidir. İşe angaje olma ve iş tatmin düzeyi genel ortalamalarına bakıldığında bu durum kolaylıkla anlaşılabilir.

Yapılan analizler neticesinde evlilerin yaptıkları işten bekârlardan daha fazla tatmin oldukları anlaşılmıştır. Söz konusu anlamlı farklılık içsel ve dışsal tatmin boyutunda da aynı şekilde görülmektedir. Ancak işe angaje olma konusunda evli ve bekar katılımcilar arasında bir farklılık yoktur. Bu nedenle $\mathbf{H}_{\mathbf{4}}$ reddedilmişve $\mathbf{H}_{5}$ kabul edilmiştir.Bu durum evlilerin bekâr kişilere nazaran daha fazla sorumluluk sahibi olmaları, düzenli bir aile hayatlarının var oluşu, evlilik hayatı ile birlikte yaşanan mutluluğun iş yaşamına olan etkisi vb. unsurlar ile açıklanabilir.

Yapılan mesleğe göre iş tatmini düzeyinde anlamlı bir farklılık olduğu, hekimlerin hemşirelere kıyasla yaptıkları işten duydukları tatmin düzeyinin daha yüksek olduğu saptanmıştır. Ancak işe angaje olma konusunda hekimler ve hemşireler arasında bir farklılık yoktur. Buna nedenle $\mathbf{H}_{6}$ reddedilmişve $\mathbf{H}_{7}$ ise kabul edilmiştir. İş tatmini konusundaki anlamlı farkl1lık hekimlerin daha iyi koşullarda çalışıyor olmaları, daha yüksek ücretler almaları ile ilişkilendirilebilir. Hemşirelerin hekimlere göre daha düşük iş tatmin düzeylerine sahip olmaları, iş yükünün fazla olması, hasta ve hasta yakınları ile çok fazla etkileşim içerisinde olmaları, bu etkileşim sonucunda yaşanan stres, hasta-hekim arasındaki iletişim mekanizmasının zayıflığı, hemşirelerin daha fazla sözlü ve fiziksel şiddete maruz kalmaları hususları ile açıklanabilir.

Yaşın ilerlemesine bağlı olarak iş tatmininin de paralel olarak arttığı yapılan analizler sonucunda anlaşılmıştır. İş tatmini, içsel ve dışsal tatmin düzeyi hekim ve hemşirelerin yaşları ilerledikçe paralel olarak artış göstermektedir. İşe angaje olma boyutlarından özdeşleşme boyutunda da yaşa göre farklılık tespit edilmiştir. Ancak işe angaje olma konusunda yaşa göre bir farklilık yoktur. Bu nedenle $\mathbf{H}_{\mathbf{8}}$ reddedilmişve $\mathbf{H}_{9}$ kabul edilmiştir. Hekim ve hemşirelerin yaşları ilerledikçe, çalışma hayatlarında daha fazla bulunup tecrübe edindikçe yaptıkları işten daha fazla memnuniyet duydukları söylenebilir. Özellikle 40 yaş ve üzeri kişilerin memnuniyet düzeylerinin yüksek olması bu hususta önemlidir. Sonuç 
olarak, yaşı daha büyük olan çalışanların kendilerini yaptıkları iş ile bir bütün olarak gördükleri ve yüksek memnuniyet düzeylerine sahip oldukları söylenebilir.

Eğitim durumu ile iş tatmin düzeyi arasında anlamlı bir farklılık olduğu görülmüştür. Çalışanların eğitim düzeyi arttıkça iş tatmin ve içsel tatmin düzeylerinin de arttığı görülmüştür. Ancak işe angaje olma konusunda eğitim düzeyleri arasında anlamlı bir farklılık yoktur. Bu nedenle $\mathbf{H}_{10}$ reddedilmişve $\mathbf{H}_{11}$ kabul edilmiştir.Bu durum, özellikle sağlık çalışanlarında oldukça önemlidir. Sağlık çalışanlarının yaptıkları işte birer uzman haline gelmeleri sağlık hizmeti sunumunu ve elde edilen sonuçları etkileyebilmektedir. Genel olarak, uzmanlık seviyesinin artması, kişinin yaptığı işte derin bilgi ve tecrübeye sahip olması ve bu durumun getirdiği daha yüksek ücret ve daha iyi koşullarda çalışma imkânı iş tatmin düzeylerini olumlu yönde etkileyebilmektedir.

Hekim ve hemşirelerin çalışma sürelerine göre içsel tatmin ve özdeşleşme boyutlarında anlamlı bir farklılık saptanmıştır.Ancak işe angaje olma ve iş tatmini konularında kıdeme göre bir farklılık yoktur. Buna göre $\mathbf{H}_{\mathbf{1 2}}$ ve $\mathbf{H}_{\mathbf{1 3}}$ reddedilmiştir.Buna göre, kişilerin kıdemi arttıkça kendi işleri ile özdeşleşme düzeyleri artmakta ve yaptıkları işten duydukları memnuniyet düzeyleri de aynı şekilde artış göstermektedir.

Aylık gelire göre iş tatmini ve içsel tatmin düzeyi anlamlı farklılık göstermektedir. Aylık gelir arttıkça iş tatmini ve içsel tatmin düzeyinin arttığı görülmüştür. Ancak işe angaje olma konusunda aylık gelire göre bir farkl1lık yoktur. $\mathrm{Bu}$ nedenle $\mathbf{H}_{14}$ reddedilmişve $\mathbf{H}_{15}$ kabul edilmiştir. Kişilerin aldığ 1 ücretin artışı, daha iyi bir hayat sağlanması, temel fizyolojik ihtiyaçların yanı sıra sosyal ihtiyaçları da fazlası ile karşılayarak kişiyi toplumda saygın bir yere taşıması bağlamında önemlidir. Çalışanların daha yüksek ücretlerde çalışıyor olmaları daha kaliteli bir yaşam sürmelerinde önemli bir araçtır. Özellikle uzman hekimlerde aylık gelirin yüksek olması bu kişilerin yaptığı işten duydukları memnuniyet düzeylerini oldukça önemli oranda etkilemektedir.

Özel hastane kapsamında yapılan bu çalışmada hekimlerin işe angaje olma ve iş tatmin düzeylerinin hemşirelerden daha yüksek olduğu anlaşılmıştır. Sağlık bakım hizmetlerinde temel birim olan hemşirelik hizmetleri çalışanlarının da bu konuda çeşitli araçlarla motive edilmesi gerekmektedir.

Çalışmanın özel sektör kapsamında ve sınırlı sayıda kişi ile yapılması araştırmanın en temel kısıtlarıdır. Benzer çalışmaların kamu sağlık kurum ve kuruluşlarında çalışan daha geniş sayıda hekim ve hemşireler ile yapılması daha genellenebilir sonuçlar açısından oldukça gereklidir.

\section{KAYNAKÇA}

Ardıç, K., Polatçı, S. (2009). Tükenmişlik Sendromu ve Madalyonun Öbür Yüzü: İşle Bütünleşme. Erciyes Üniversitesi İktisadi ve İdari Bilimler Fakültesi Dergisi, 32, 21-46.

Aziri, B. (2011). Job Satisfaction: A Literature Review. Management Research and Practice, 3(4), 77-86.

Bal, E. A. (2009). Bir Pozitif Psikoloji Kavramı Olarak İşe Gönülden Adanma (Work Engagement) ve İnsan Kaynakları Açısından Önemi. Eskişehir Osmangazi Üniversitesi İşletme Bölümü 17. Ulusal Yönetim ve Organizasyon Kongresi, 21-23 May1s, 546-552. 
Chaulagain, N., Khadka, D. K. (2012). Factors Influencing Job Satisfaction Among Healthcare Professionals At Tilganga Eye Centre, Kathmandu, Nepal. International Journal of Scientific \& Technology Research, 1(11), 32-36.

Crisp, N., Chen, L. (2014). Global Supply of Health Professionals. The New England Journal of Medicine, 370(10), 950-957.

Güneşer, A. B. (2007). TheEffect Of Person-Organizatıon Fit On Organizational Commitment and Work Engagement: The Role Of Personsupervisor Fit, (Yayımlanmamış Doktora Tezi). MarmaraÜniversitesi/Sosyal Bilimler Enstitüsü, İstanbul.

Hyun, S. (2009). Re-Examination of Herzberg's Two-Factor Theory of Motivation in The Korean Army Food service Operation, 1-54, http://Lib.Dr.İastate.Edu/Etd.

Kumar, R., Ahmed, J., Shaikh, B. T., Hafeez, R., Hafeez, A. (2013). Job satisfaction among public health professionals working in public sector: a cross sectional study from Pakistan. Human Resources for Health, 11(2), 1-5.

Markos, S., Sridevi M. S. (2010). Employee Engagement: The Key to Improving Performance. International Journal of Business and Management, 5(12), 89-96.

Maslach, C., Schaufeli, W. B., Leiter, M. P. (2001). Jop Burnout. Annual Reviews, 52, 397-422.

Maslach, C., Leiter, M. P. (2008). Early Predictors of Job Burnout and Engagement.Journal of Applied Psychology, 93(3), 498-512.

Mordelet, P. (2013). The impact of globalisation on hospital management: Corporate governance rules in both public and private nonprofit hospitals. Journal of Management \& Marketing in Healthcare, 2(1), 7-14.

Mosadeghrad, A. M., Ferdosi, M. (2013). Leadership, Job Satisfaction and Organizational Commitment in Healthcare Sector: Proposing and Testing a Model, Mat Soc Med, 25(2), 121-126.

Neuman, W. L. (2014). Social Research Methods; Qualitative and Quantitative Approaches, 7. Bask1, Pearson Yayınları, United States of America.

Öner, Z. H.(2008). The Mediating Effect Of Organizational Justice : Moderating Roles Of Sende Of Coherence And Job Complexity On The Relationship Between Servant Leadership And Work Engagement. (Yayınlanmamış Doktora Tezi). Marmara Üniversitesi/Sosyal Bilimler Enstitüsü, İstanbul.

Özer, Ö., Saygılı, M., Uğurluoğlu, Ö. (2015). Sağlık Çalışanlarının İşe Cezbolma Düzeylerinin Belirlenmesine İlişkin Bir Araştırma. Business \& Management Studies: An International Journal, 3(3), 261-272.

Paşamehmetoğlu, A., Yeloğlu, H. O. (2013). Motivasyon Kuramları. Ünsal Sığrı ve Sait Gürbüz (Ed.), Örgütsel Davranış (s. 141-165). İstanbul: Beta Basım Yayım Dağıtım.

Ravikumar, T. (2013). A Study On Impact Of Team Work, Work Culture, Leadershıp And Compensation On Engagement Level Of Employees In Msmes In India. International Journal of Advanced Research in Management and Social Sciences, 2(8), 175-185.

Robbins, S. P., Judge, T. A. (2012). Tutumlar ve İş Tatmini, Örgütsel Davranış (s. 71-97), İnci Erdem (Ed.), 14. Bask1, İstanbul: Nobel Yayınları.

Robinson, D., Perryman, S., Hayday, S. (2004). The Drivers of Employee Engagement.Institute for Employment Studies: Brighton, 1-73.

Schaufeli, W. S., M. Gonza'lez-Roma, V., Bakker, A. B. (2002). The Measurement of Engagement and Burnout: A two Sample Confirmatory Factor Analytic Approach. The Journal of Happiness Studies, 3, 71-92.

Schaufeli, W. B., Bakker, A. (2003). Utrecht Work Engagement Scale. Occupational Health Psychology Unit, Utrecht University, 1-58.

Schaufeli, W. B. (2015). Engaging Leadership in the Job Demands-Resources Model. Career Development International, 20(5), 446-463.

Tengilimoğlu D., Işık O., Akbolat, M. (2012). Sağlık İşletmeleri Yönetimi. 4. Baskı. Ankara: Nobel Akademik Yayıncılık.

Will, J. W., Powell, P. (2009). The National healthcare crisis: Is eHealth a key solution?. Business Horizons, 52, 265-277. 


\section{SUMMARY}

When anyone feels the need health services, which is related to the right to life of the whole of the population living in a country, it must be met. Everyone has the right to the protection and development of human health. In this context, the importance of health care professionals, especially physicians and nurses, emergesas the basic providers of health care. The World Health Organization (WHO) refers to health care workers as one of the building blocks of the health system. The role of health care workers in a health care system is indispensable.Health care quality, effectiveness, etc. are linked to the process of service delivery. How the health careis presented and the behavior of the health workers arehighly effective on the planned outputs obtained from this care. Therefore, they shouldlove the job, be committed and sincere in their work forthe development and protection of public health. So, level of work engagement of the employee is quite important. Similarly, job satisfaction level of the employees effects the quality and effectiveness of health services. Thus, this study aims to determine work engagement and job satisfaction level of physicians and nurses, and examine whether there is a correlation between the two variables. Also, it aims to determine whether work engagement and job satisfaction level differ by demographic variables. This study was conducted at a private hospital in the province of Izmir by using face to face survey method. The survey consists of "Work Engagement" and "Minnesota Job Satisfaction" scales. There are 35 doctors and 50 nurses in the hospital. In this study, 44 nurses and 16 physicians were included. The data obtained were transferred to a computer and then percentage (\%), frequency (f), arithmetic mean ( $\bar{X}$ ), Kruskal-Wallis H, Mann Whitney U and Spearman's rho correlation analysis were examined by using the program SPSS 20.0. Tests of normality (Kolmogorov-Smirnov and Shapiro-Wilk) were applied and it was clarified that the data did not demonstrate normal distribution. Therefore, non-parametric tests were applied.

In the result of the analysis, it is revealed that work engagement and job satisfaction level of physicians and nurses are high; there is a significant positive relationshipbetween work engagement and job satisfaction. Work engagement and job satisfaction level differ by gender. Work engagement and job satisfaction level of men are higher than women. Job satisfactionlevel varies by marital status, and married are more engaged than singles. Job satisfaction level varies by occupation performed, and job satisfaction level ofphysicians are higher than nurses. Job satisfaction level varies by age, and it is found out that job satisfaction level is also increased along with the age. Job satisfaction level differsby the educational level. As educational level of physicians and nurses increases, job satisfaction level increases as well. The job satisfaction level and identification status varyby seniority. As seniority increases, job satisfaction level ofphysicians and nurses and identificationwith the work increases. Job satisfaction level differs by monthly income. As income level rises, an increase in job satisfaction level of physicians and nurses has been observed. The high level work engagement and job satisfaction of physicians and nurses, who are the basic providers of 
healthcare, is quite important.Health professionals dedicating themselves to serve the people that exist within the health system andenthusiastically loving what they do are remarkable. However, there is a significant difference between physicians and nurses regarding the job satisfaction level. Nurses' job satisfactionlevel is lower than physicians. This study was made in a private hospital. Sincea nurse in private hospitalearns a lower salary compared to a nurse who works in public hospital and the workload is heavier in private hospitals, nurses in a private hospital are expected to have a lowerlevel of job satisfaction. 